\title{
日本植民地期における韓国の日本人移住漁村の形成に関する研究 \\ 一巨文島・巨文港を対象として \\ FORMATION OF JAPANESE MIGRANT FISHING VILLAGE COLONY IN KOREA \\ -In the case of Geomun-do island
}

\author{
朴 重 信*，布 野修司**
}

Chungshin PARK and Shuji FUNO

\begin{abstract}
This paper aims to clarify the formation process of migrant fishing village of Japanese during their colonization of Korea. Research reveals the background and formation of Japanese migratory process in order to illustrate their fishing village forms and spatial pattern by raising Geomun-do Island as a case study. In this research, we clarify formation process and spatial pattern of its village. Clarifying of functional development process of the village is also another objective of this research. It appears that coastline and its roads, wells and location of progenitor's settlement plays a vital role in form and spatial structure of the village. Road system of the village was constituted from roads running parallel with coastline and small alleys stretching perpendicularly to them providing trapezoid shape of lands. As places for housework or community gathering places, two wells adjacent to the progenitor's premises play a significant part as cores of housing development of the village. Though this seashore village is tiny in scale, fishing, trade and pastime activities provide a multi-facet function to the village as other modern cities.
\end{abstract}

Keywords: Japanese migrant fishing village, Government supported fishing village, Privately initiated fishing village, Formation, Spatial form 日本人移住漁村、補助移住漁村、自由移住漁村、形成過程、集落空間構造

1. はじめに

\section{1-1 研究の目的と意義}

本研究は、1800 年代末から韓国の各地に日本人が移住し、住み着いた 日本人移住漁村を対象として、移住の背景とその形成過程を考察した上で、 日本人移住漁村の空間構造とその変容過程を分析し、集落形態及び空間 構成を明らかにすることを目的とする。本稿では、日本人移住漁村の中で 日本人の居住世帯比率が最も高い漁村であった巨文島の巨文港を取り 上げ、その形成過程と集落の空間構成、都市的機能形成過程を解明する。 1800 年代末から始まった日本人の韓国漁村への移住に関する文献は、 主に朝鮮総督府の調查資料や水産局の資料に基づいて作成されたもの が多い。その中で、主要なものは吉田敬市と孫禎睦の研究がある。吉田敬 市の「朝鮮水産開発史」*1 は、日本人が移住してつくった漁村を「補助移住 漁村」と「自由移住漁村」に分けて明らかにしている。朝鮮近海の自然地理、 港湾の状況、水産技術水準などを詳しく論じている。一方、孫禎睦は「日帝 強占期都市化過程研究 ${ }^{* 2}$ で、漁港都市の形成の過程と日本漁民の通漁

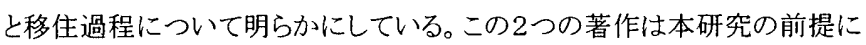
なっている。

また、巨文島に関する文献は、他の島と比べると比較的多い。それは地 政学的に重要な意味があり、外国勢力の侵略を受けやすい島であったか らである。島の歴史については時期別に様々な記録や歴史書*3 が残され ているが、近代史を概括したものとして敦永甫の「巨文島風雲史」*4 があり、 当時の巨文島の地政学的な位置づけを理解する上で重要である。日本人 による巨文島の開拓に関する研究としては、文化人類学の分野で崔吉成 ${ }^{* 5}$ や中村均 $* 6$ の著書がある。崔は民俗文化の側面から日韓の文化変容に焦 点を当て、中村は国際交流史の観点から論じている。他に英国の巨文島

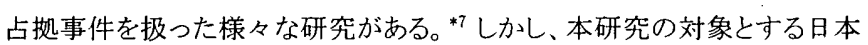
人移住漁村である巨文島の空間構成や建築的特性について論じているも のは皆無である。

日本人移住漁村は、日本人の移住により開拓され、その漁村の大半は その後韓国の主要漁港になったという経緯がある。また、巨文島は様々な 葛藤や衝突を引き起こした韓国各地の都市の場合と異なり、無人島を近代 的な漁村として建設したという点に特徴がある。 ${ }^{* 8}$ 現在でも、当時の建物が 数多く残っており、道路の幅や町並みの規模などもほとんど当時の状態の ままである。その故、巨文島の形成過程を考察することにより、韓国各地の 日本人移住漁村の空間構成原理、集落形態を解明する手がかりを得ること ができる。

\section{1-2 調査概要}

本研究を行うにあたり、二度にわたり巨文島 へ赴き、文献・地図の資料を収集するとともに 現地調查を行った。第 1 次調査は、2000年8月 21〜31日にかけて行った。資料収集を行うとと もに、麗水市製作の地籍図の複写 $(1 / 1,200)$ と 韓国国土地理院製作の航測図(1/3,000)を下 敷きとして、島の全地域の施設分布、建築類 型(建築年度、用途、構造、階数)を主とする悉 皆調査を行い、施設分布図を作成した。また、 道幅の測定、井戸の位置などの個別調查を行 った。第2次調查は2002年8月19〜23日にか けて、資料収集を行うとともに集落の変遷過程 に関するヒアリング調查を行った。

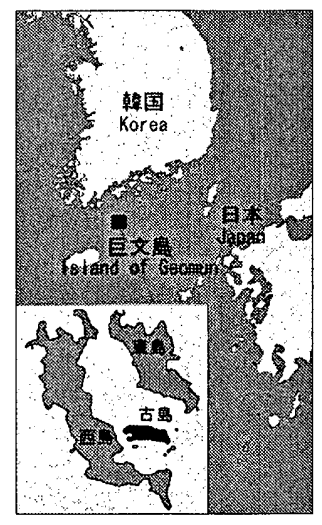

[図1]巨文島の位置図
* 京都大学大学院工学研究科 博士後期課程 $\cdot$ 工修

** 京都大学大学院工学研究科 助教授. 工博
Graduate Student, Dept. of Architecture and Environmental Design, Kyoto University, M. Eng.

Assoc. Prof., Dept. of Architecture and Environmental Design, Kyoto University, Dr. Eng. 


\section{2. 日本人移住漁村の形成と発展}

\section{2-1 日本漁民の朝鮮通魚と保護桨励策}

日本人の海外移住は 1885 年 $($ 明治 18 年)頃から始まる。明治 10 年代の全国的 な経済不況と自然災害などが原因で、 農業及び漁業移民が主にハワイ、北アメ リカ、ブラジルなどに渡った。朝鮮半島 への漁業移民の場合も同様な背景があ り、漁村の不況と日本政府の後押しがあ った。長く鎖国政策を行っていた朝鮮政 府は「日韓修好条規」(1876年)により、日 本に対して開国し、釜山を開港場として 日本人の居住と通商を認めた。これは、 一般物資の通商のみを認可したもので、 通漁の自由を認めたわけではなかった。 日本漁民の朝鮮沿海の通漁が正式に 認可されたのは1883年7月の「在朝鮮国

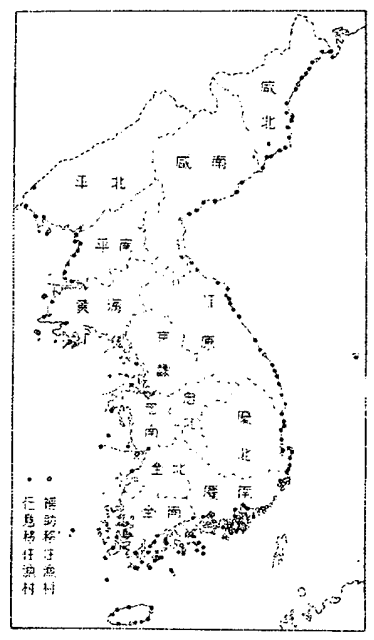

[図2]日本人移住漁村の分布 (吉田敬市、1954)
日本人民通商章程」が締結されてから

である。1889年12月には「日朝両国通漁章程」が締結され、日本漁民の韓 国近海の通漁がより円滑になった。続いて、1890年(明治23年)に「日本朝 鮮両国通魚規則」が公布され、日本漁船が朝鮮近海に出漁するようになる。 1897年(明治30年)には「遠洋漁業奨励補助法」を発布し、1898年(明治31 年)に農商務省水産局長を韓国へ派遣調查させ、その結果府県毎に「韓海
通漁組合」(1900年)が組織されることになった。さらに「朝鮮海通漁組合連 合会」(1902年)が設置され、その本部を釜山に置き、朝鮮海水産業開発の 助長機関とした。以上のような日本政府の保護奨励策は各府県においても 継承され、各地の水産試験場や漁業組合は韓国の南海(ナンへ)進出のた め、様々な方策が採られた。

\section{2-2 補助移住漁村と自由移住漁村}

1904年2月、日本政府がロシアとの国交断絶を通告し、「日韓議定書」を 締結する。続いて、1908年10月には、「日韓漁業協定」を結び、11月には 「韓国通漁法」と「漁業法施行細則」が制定・発布された。この3つは、日本 漁民の韓半島の定着と通漁がより有利に進められるように支援するもので あり、韓国内に「補助移住漁村」を形成させる制度的装置であった。「補助 移住漁村」が本格化されたのは「日韓漁業協定」が締結された1908年前後 である。「補助移住漁村」点建設した背景には次のような点がある。

1)これまでの日本漁村の韓海通漁は往復に多くの日数が必要であり、遭 難などの危険があったこと

2)日本国内の人口增加、資本主義的経済発展による植民的移住熱が高 まったこと

3)日本の大陸政策の立場で、朝鮮の移住漁村の建設は必要不可欠で あったこと

4)1908年に「漁業法」を発布し、この漁業法による漁業権の免許·許可は 韓国内居住者に限られたこと

一方、「自由移住漁村」というのは、日本人が任意で韓国各地に移住し て住み着いた漁村である。こうした「自由移住漁村」は、計画性を持ってい

[表1］日本植民地期の著名漁港(1929年末現在、北朝鮮を除いて)

\begin{tabular}{|c|c|c|c|c|c|c|c|c|c|c|c|c|}
\hline \multirow{2}{*}{ 位置 } & \multirow{2}{*}{ 道 郡 面 洞理 } & \multirow{2}{*}{ 移住年度 } & \multirow{2}{*}{ 種別 } & \multirow{2}{*}{ 別称 } & \multirow{2}{*}{ 主要内容 } & \multirow{2}{*}{ 主要産物 } & \multicolumn{2}{|c|}{ 日本人 } & \multicolumn{2}{|c|}{ 韓国人 } & \multicolumn{2}{|c|}{ 計 } \\
\hline & & & & & & & 戸 & 人口 & 戸 & 人口 & 戸 & 人口 \\
\hline 西 & 全北沃满郡米面京場里 & - & - & - & - & - & 23 & 109 & 445 & 3,067 & 468 & 3,176 \\
\hline \multirow[t]{19}{*}{ 南 } & 全南済州郡済州面三徒里 & 1879(明12) & 自 $\rightarrow$ 補 & - & 潜水業者の根挻地 & タイ、イカ、イワシ & 35 & 119 & 530 & 2,586 & 568 & 2,713 \\
\hline & 右面西帰浦 & 1879(明12) & 自 $\rightarrow$ 補 & - & 同上 & 闹上 & 40 & 167 & 303 & 1,438 & 350 & 1,630 \\
\hline & 大静面下墓里 & 1879(明12) & 自 $\rightarrow$ 補 & 古浦 & 同上 & 闹上 & 9 & 33 & 492 & 2,022 & 503 & 2,060 \\
\hline & 新左面咸德里 & 1879(明12) & 自一補 & 城山浦 & 同上 & 同上 & - & - & 648 & 2,660 & 648 & 2,660 \\
\hline & 莞島郡案島面郡内里 & 1893(明 26) & 自 & 所安島 & 同上 & - & 82 & 380 & 294 & 1,722 & 385 & 2,133 \\
\hline & 高興郡道陽面鳳岩里 & - & - & - & - & - & 14 & 57 & 452 & 2,644 & 467 & 2,715 \\
\hline & 蓬莱面外蘇老島 & 1894(明 27) & 自 $\rightarrow$ 補 & なし & エビ製造業の中心地 & 海老、 & 83 & 380 & 215 & 1,249 & 298 & 1,630 \\
\hline & 融水郡麗水面東町 & 1912(明45) & 自 $\rightarrow$ 補 & 広島村、愛知村 & 八モの中心地 & 鰽 & 281 & 1,139 & 729 & 4,919 & 1,014 & 6,072 \\
\hline & 突山面郡内里 & - & - & - & - & - & 9 & 27 & 330 & 2,068 & 339 & 2,095 \\
\hline & 三山面巨文里 & 1905(明38) & 自 $\rightarrow$ 補 & なし & サバ巾着の最大根拠地 & $サ ハ$ & 110 & 376 & 72 & 224 & 184 & 605 \\
\hline & 慶南南海郡三東面弥助理 & 1909(明42) & 自 $\rightarrow$ 補 & 佐賀村 & サバからイワシに転向 & サバ、イワシ & 46 & 168 & 318 & 1,681 & 367 & 1,854 \\
\hline & 泗川郡三千浦面仙亀理 & 1911(明44) & 補 & 愛媛村、山口村 & 消隇 & 遠淮漁業 & 27 & 111 & 241 & 1,328 & 269 & 1,443 \\
\hline & 固城郡東海面壯佐里 & 1912(明45) & 補 & 槰檖津 & サバ経営 & サバ & 32 & 164 & 212 & 1,225 & 244 & 1,389 \\
\hline & 統営郡統営面吉野町 & 1900(明33) & 自 $\rightarrow$ 補 & 島根村、長崎村 & 南鮮屈指の商業・水産都市 & イワジ網漁業 & 296 & 1,315 & 331 & 2,151 & 628 & 3,472 \\
\hline & 欲知島東港洞 & 1899(明32) & 自 $\rightarrow$ 補 & 山口村 & サバ漁業の根拠地 & イワジサバ & 69 & 413 & 675 & 4,374 & 744 & 4,787 \\
\hline & 巨済郡二運面長承浦 & 1904(明37) & 自 $\rightarrow$ 補 & 入佐村 & サバ巾着の最大根拠地 & 鯖 & 162 & 675 & 219 & 1,451 & 386 & 2,138 \\
\hline & 沙等面倉湖里 & 1910(明43) & 自 $\rightarrow$ 補 & 城浦 & イワシ網漁業 & イワジサケ & 2 & 9 & 362 & 2,212 & 364 & 2,221 \\
\hline & 昌原郡鎮海面慶和洞 & 1912(明45) & 補 & 鎮海漁港 & 消滅 & 遠漜漁業 & 95 & 428 & 986 & 5,335 & 1,089 & 5,793 \\
\hline & 東莱郡沙下面多大浦 & 1906(明 39) & 自 $\rightarrow$ 補 & なし & 消滅 & 丑イ & 62 & 234 & 802 & 4,601 & 864 & 4,835 \\
\hline \multirow[t]{11}{*}{ 東 } & 慶南蔚山郡東面方魚津 & 1903(明36) & 自 $\rightarrow$ 補 & 福井村、香川村 & サバ漁業の最大根拠地 & サバ、鰆、 & 349 & 1,456 & 431 & 2,257 & 783 & 3,725 \\
\hline & 慶北慶州郡陽北面甘浦里 & 1907(明 40) & 自 $\rightarrow$ 補 & 福井村 & サバ漁業の根拠地 & サバ,イワシ & 196 & 742 & 518 & 2,130 & 719 & 2,885 \\
\hline & 迎日郡滄州面九龍浦 & 1910(明43) & 自 & なし & 漁業兼運搬業者の根拠地 & サバ & 192 & 815 & 342 & 1,836 & 543 & 2,686 \\
\hline & 浦項面浦項洞 & 1903(明36) & 自 $\rightarrow$ 補 & なし & 物資交易の市場、午詰 & イワシ & 436 & 1,838 & 1,090 & 5,071 & 1,539 & 6,968 \\
\hline & \begin{tabular}{|c|} 
盆徳郡盆徳面江口理 \\
\end{tabular} & 1910(明 43) & 自 & なし & 河港、密漁者の根拠地 & サワラ & 27 & 185 & 189 & 1,064 & 219 & 1,262 \\
\hline & ウルン島南面道洞 & - & - & - & - & - & 120 & 408 & 186 & 1,293 & 309 & 1,711 \\
\hline & 江原三陟郡三陟面汀下里 & - & - & - & - & - & 30 & 116 & 104 & 1,062 & 134 & 1,178 \\
\hline & 遠徳面臨院里 & - & - & - & - & - & 15 & 106 & 207 & 1,223 & 222 & 1,329 \\
\hline & 江陵郡新里面注文津 & 1908(明41) & 自 & なし & 潜水漁業の根拠地 & イワシ & 39 & 232 & 481 & 3,584 & 522 & 3,845 \\
\hline & 高城郡新北面長箭里 & 1908(明41) & 自 & なし & 江原道最大の根拠地 & タラ、サバ、明太 & 49 & 205 & 275 & 1,400 & 334 & 1,620 \\
\hline & 通川郡順嶺面下庫底里 & - & - & - & - & - & 28 & 122 & 280 & 1,868 & 313 & 2,104 \\
\hline
\end{tabular}


た「補助移住漁村」とはその成立動機、機構、そして発展過程などがまった く異なる。そして、「補助移住漁村」の移住民の大半が漁民であったのに対 して「自由移住漁村」では、漁民と元運搬業者や一般商人が漁港に定着し、 その中は漁業に転業した人もあった。

吉田敬甫は「自由移住漁村」を次のように分類している。 ${ }^{* 9}$

1)通業者が任意に移住して定着した漁村一大部分の漁村

2)制限付き許可移住漁村一鎮南浦

3)補助・自由の両移民混在漁村

(1)最初は補助移住漁村であったが、自由移住漁村に変わった漁村 一蔚珍郡竹辺

(2)最初は自由移住漁村であったが、補助移住漁村に変わった漁村

一郡山、統営、巨文島

(3)元は(2)であったが、再び自由移住漁村に変わった漁村

一方魚津、巨済島一運面

4)水産物の製造にため立地した漁村一済州島、黒山島、外羅老島

5)個人経営の移住漁村一蔚山郡西生面新岩

以上のような、日本の漁民や水産業者の自由移住定着は、1870年代末 の釜山の影島を皮切りに、済州島・元山・仁川・羅老島・郡山・大黒山島・ 木浦·鎮南浦·馬山・統営につながった。東海(日本海)には、方魚津・浦項・ 甘浦・九龍浦などは1900年代に入ってから移住定着が行われた。東海の 北の方には、1910年代に入ってから定着が行われたが、これは海岸線の 屈曲が少ないため、港湾の建設がしにくいからであった[図2]。

\section{2-3 主要漁港への発展}

韓国の漁港が本格的に形成・発達したのは、日本植民地期の1920年代 以後からで、その背景には日本人の漁民の韓国への移住があった。日本 漁民は韓半島の全沿海に散在して優秀な漁具・漁法と近代的漁業経営を 通じて漁場を独占するようになる。

しかし、1910年代までは漁港としてその本質的な機能を果たしている漁 港集落が極めて少なかった。1910年の総督府統計年報の「主要市街地の 現住戸口表」によると、純粋な意味での市街地は、麗水、法聖浦、統営、方 漁津、長生浦、長承浦などの9カ所だけであった。1910年代まで発展できな かったのは日本人と韓国人とも定着者が少なかったことがその原因であっ たが、それ以外にも次のような理由があった。

その一つは、漁具·漁船の未発達による水産業の零細性であった。当時 の日韓の水産関係史によると漁船の場合、「1907年代末現在、朝鮮におけ る漁船の数は朝鮮型9,070隻、日本型3,015隻である。しかし、1920年代に 入って漁船改良を行った結果、朝鮮型は1.5倍、日本型は4倍に增加し た。」この資料で10年間の漁船の普及事情がわかる。二つは、港湾施設で ある。韓国の各港湾に防波堤、停泊地のように近代的な港湾施設が築造さ れたのは自由移住漁村がつくられた以降の1912年頃である。 ${ }^{* 10}$

以降、1910年代の後半からは統営を中心に、麗水、長承浦、三千浦、方 漁津、甘浦、九龍浦、注文津、長箭、新浦の漁港が有名になり、1930年代 の前後には[表1]に示したように数多くの主要漁港が形成された。

\section{3. 巨文島の日本人移住漁村}

\section{3-1 巨文島の地理的環境と歴史的背景}

巨文島は韓半島の最南端に位置し、東島、西島、古島の 3 つ有人島と 50 余りの大小の無人島で構成されている。済州島(ジェジュド)を除けば韓 国の本土から最も離れた島で、昔から中国、韓国、日本を繁ぐ海上交通の 要衝である。研究対象の古島(行政区域名: 全羅南道麗水郡三山面巨文
里)は、西島と東島に挟まれ、周辺の海の水深が媣くて安全な天然の港湾 となっている。島の面積は $1.11 \mathrm{~km}^{2}(33$ 万坪)、人口は776人(260戸、2000年 統計)である。気候は結水がほとんどない温暖な海洋性気候である。

1)海上の道と巨文島

巨文島について最初に議論できるのは、日本から外国へ行く出航のこと を歌った7〜8世紀の「万葉集」である。 ${ }^{* 11}$ 当時の海外出航は、主に九州から 新羅や唐一派遣された外交使節であり、6世紀から3世紀間にわたって往 来し日本の政治、制度、文化に大きな影響を与えた。このころの外交使節 の海上交通路には4つのコーズ12があった。これらのうち2つの航路は巨文 島に立ち寄るか、付近を航海するものである。また、台風の避難港としても 使われており、当時の巨文島は海上航路の要衝地であった。

2）19世紀の砲艦外交とロシア艦隊の来航

英国は、1840年から42年にかけて中国との間にアヘン戦争を起こしたた め、対日政策にかかる余裕がなかった。一方、米国は東洋航路の中継基 地として日本に開港を迫るため、4隻の軍艦を派遣した。ペリーPerry(1794 〜1858)提督の東インド艦隊が1853年6月、浦賀人来航して開港を要求し、 翌年3月「日米和親条約」を締結寸る。これに驚いたロシア政府は、プチャ 一チンPutyatin(1803〜1883)中将を遣日大使に任命し艦隊を派遣する。 1852年10月、バルト海のクロンシュタット港を出港し、1853年7月長崎に入 港した。同年8月に国書を伝達して開港を迫り、翌年11月に「日露和親条 約」を結ぶ。この対日開港交渉中、ロシアのプチャーチン艦隊は1954年4月 4日から19日間巨文島に寄港した。注これが所謂「ロシア艦隊巨文島侵入 事件」である。巨文島においてプチャーチンの巨文島来航の歴史的意味 は、(1)韓・露関係史上初めてロシア人が訪れ、開港を要求したこと、(2)巨文 島が戦略的集結地として使われたことである。

3)英国の巨文島占拠事件

19世紀、中国とのアへン戦争で勝利した英国は、ロシアの南下政策を牵 制するため、重要な軍事要衝地として巨文島を占領することを決めた。そし て1885年(明治18年)4月、W.ドーウェルDowell中将が率いる英国海軍が巨 文島を不法占拠し、英国旗を揚げたのである。これは巨文島史上 2 度目の 外国軍艦による不法寄港であり、初めての強制占拠であった。占拠後、こ の島を「Observatory Island」と命名し、要塞化するために古島に観測所や 砲台を設置し、宿所、食堂、医療施設などを建設した。しかし、この不法占 領を巡って国際社会から「第2の香港」と非難される。朝鮮から強く抗議され、 またロシア、清、日本との国際問題となるのを避けるため、英国海軍は1887 年3月に約23ヶ月間占領した巨文島から撤退した。この事件によって朝鮮 の社会や人々の実情は広く西欧社会に知らされた。

\section{3-2 島の開拓とパイオニア}

明治維新によって鎖国から解き放された日本国内の漁業は生産の 飽和点を打ち破るため海外一急激に進出し、とりわけ西南日本の漁 業者たちの朝鮮近海への出漁が、1876年 (明治9年)の日韓修好条規 (江華条約) 批准とともに急増した。こうした背景のもとで無人島で あった古島 (ゴド、巨文里)に1905年、最初に移住して住み着いたパ イオニアは木村忠太郎 (漁師) と小山光正 (郵政技師)である。 1)漁師 木村忠太郎

1905年(明治38年)、山口県豊浦郡の湯玉浦という漁村では家屋170軒が 完全焼失する大火事が起き、その漁村に住んでいた木村忠太郎は家屋や 家財などを一切失ってしまう。木村は再起を賭けて、それまでしばしば付近 に出漁して知識のあった古島への移住を決意し、妻リムと三男を連れて故 郷を離れる。1905年(明治38年)4月、巨文島に上陸して、船溜まりとなった 
入り江に面する平地に草蒀きの小屋を建てた。

2)郵政技士 小山光正

小山光正は、鳥取県出身の土族と伝えられ、 1904年(明治37年)巨文島の戦略的重要性を認 識した日本政府の命を受け、日露戦争時代に巨 文島の西島に敷設された海底電線の維持管理 を任務とする郵政技師として派遗された。1906年 (明治38年)には、巨文島郵便所の許可を得て海 底電線を巨文島(古島)一敷設し、自ら数年間所 長を勤めた。

\section{3-3 近代的漁港としての発展とその過程 ${ }^{* 15}$}

巨文島は、当初は自由移民漁村として出発し たものの、前述したように日本の政府からの一連 の措置にしたがって䊀次、漁業基盤を確立して いった。特に、1923年4月には「指定港」になり、 文化的·行政的中心である麗水市に劣らぬ盛況 ぶりを見せるほど発展したのである[図5]。

1)明治末期(1905年ごろ)-3戸7人〜9人

最初に移住した木村忠太郎の住居、倉庫、作 業所、小山光正と大野栄太郎の戸建て住宅が建てられた。また、出漁の安 全と大漁を祈るため、金比羅宮の小祠が南側の低い丘に造られた。

2）大正初期〜大正末期(1910年代)

-15戸47人

この時期には主に住宅が建てられ、既に住み始めた場所周辺と井戸が ある所を中心に海岸線に沿って開 発された。また、山の丘へ通じる路 地は海岸線に直行する形で形成さ れ始め、海岸道路とともに村の道路 体系の基般となった。

3）大正末期 昭和初期

(1920年代)-98戸 360 人

南側の磯の部分がほとんど埋め 立てられ、海岸道路が形成される。 この海岸沿いに住宅、店舗、旅館 などが建て込み、町並みがほぼ完 成した。役所、警察署、郵便所など が建てられ、魚市場や漁業関連施 設(造船所、鉄工所、製水所等)、宗 教施設も新たにつくられた。

4）昭和初期〜昭和 15 年頃

（1930年代一 40年代初）- 99 戸 347 人

道路や漁港施設が整備され、三 日月形の海岸道路に沿って町並み が完成した。大きな変化は本格的 な漁港として防波提が作られ、南方 に海底電線が敷設されたことである。 また、教育・医療施設と遊興施設 (風呂屋、遊遊、料亭、喫茶店等)を 中心に様々な施設が増えた。

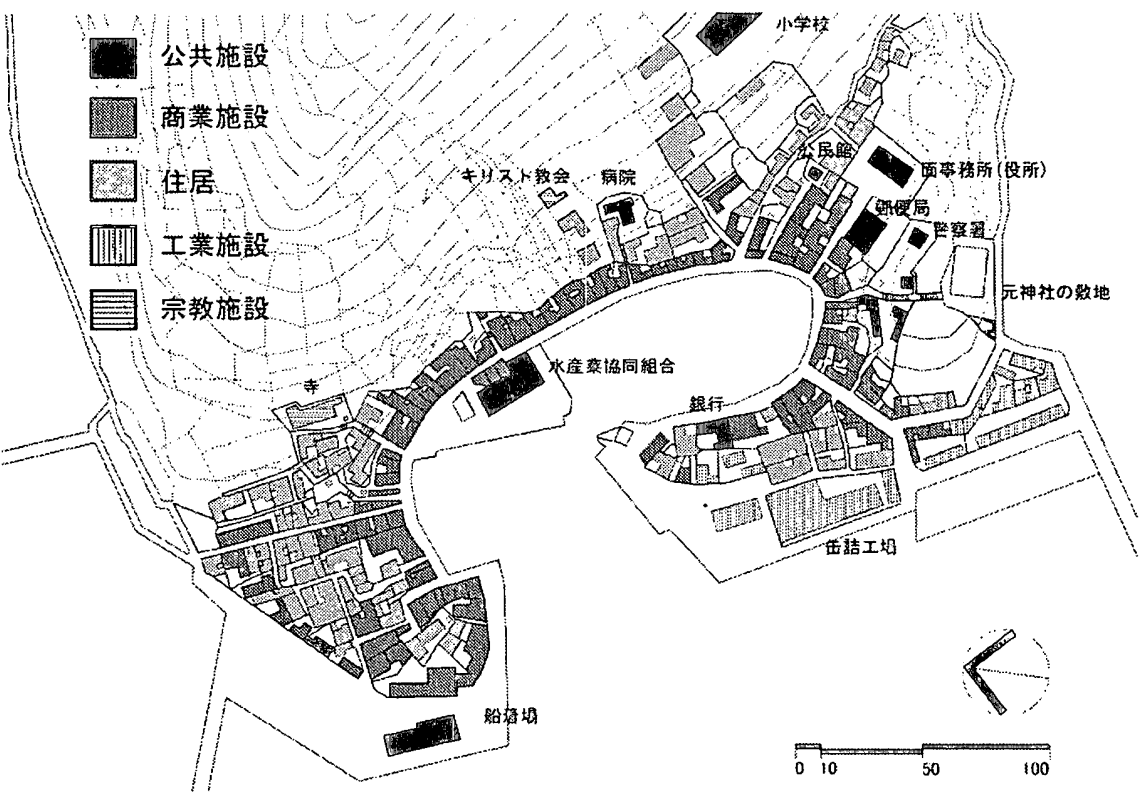

[図4] 現在の巨文港の施設分布

\section{4. 空間構造の特性 \\ 4-1 施設分布}

巨文港の施設分布は住居、商業施設、公共施設、宗教施設、工業施設 の5つに大別される[図4。施設分布に基づいて建物の用途に着目してみ ると、巨文港の空間構造は以下のような特徵を持つ。

1)商業施設

商業施設は主に三日，型の海岸道路に並行して並び、その大部分が2 階に住居を持つ店舗併用住宅である。その機能としては、スーパー・マー ケット、飲食店、雑貨屋(主に、釣り道具や餉を扱っている)、カラオケ、宿泊 施設、喫茶店、銭湯などがあり、その中で飲食店、宿泊施設、喫茶店が商 業施設の約7割(商業施設の103戸の内、71戸)を占めている。

2)住居

住居は海岸道路沿いゆ店舗併用住宅以外、主に漁港の北端部に密集 しており、他には街区内部に点在する程度である。その特徵は、漁港の北 端部の住居地を除けば、街区内部の住居地はほとんど島の地形に対応し て階段式に構成されていることである。また、住居の大半は1945年以後、 部分的に増築・改造されているが、全体的な形はあまり变わっていない。

3)公共施設

主要な公共施設としては、面 ${ }^{* 16}$ 事務所(役所)、警察署、郵便局、小学校、 金融機関(銀行、相互金庫など)、消防署、医療施設、公民館、船着場など がある。金融譏関と船着場を除けば、ほとんど漁港の南側に集中している。 特に、公民館は新しい面事務所が1959年に建てられて移転するまで面事 務所として使われていた。機能は変化したものの、その建築様式は現在も 当時のままである。また、郵便局の場合はパイオニアである小山光正が誘 致した時の位置から離れ、面事務所の入口の隣に位置している。

こうした公共施設が漁港の南側に集中してつくられた背景には、公務員 出身である小山光正が1917年に設立された「巨文島漁業共同組合」の組 合長をつとめ、行政の集中化を求め、郵便所の周辺に役所、警察署、消防 署などの公共施設の敷地を決めるのに大きい影響力を持っていたことがあ る。 


\section{4)宗教施設}

宗教施設としては、キリスト教、仏教のための施設がある。具体的には入 江東側の敷地の奥にキリ不教会と寺がそれぞれ一つずつ位置する。1920 年代の地図からみると、寺の場合、南東の方に二つの寺(净土真宗と大師 堂)が存在していたが、現在は別の場所に新たに建造されたことが分かる。 キリスト教会は1953年に建てられた。

一方、現存しないが、入り江南端の小高い丘の上に三島神社が造られ たという事実がある。開拓当時には金比羅宮の小祠であったが、これが後 「三島神社」あるいは「三島神祠」に発展し、1940年には「紀元二千六百年 記念事業」*17の一環として大改築·造営された。現在には、その敷地内には 小柌の跡と築港記念碑だけが残っており、鳥居は切断されて船の舫い網を 慗ぎ止める杭となった。

\section{5)工業施設}

漁港の南西端部には工業施設が密集している。その種類は、鉄工所、 製氷所、缶詰工場、発電所、倉庫など、主に漁業関連の工業施設である。 こうした工業施設の密集の背景には「指定港指定制度」*18があった。1924 年に「指定港」としての昇格され、日本政府から支援を受けることになり、そ れまで整備できなかった南側の磯の部分を埋立て、その敷地に建てられた のである。特に、製氷所は公共性が強い施設であって、港湾施設の一部之 して建てられたといら特徴がある。

\section{4-2 街区構成と街路体系}

現在、漁港 の街区構成及 び街路体系は 日本植民地時 代とほぼ同様で ある。街路体系 の軸になる海岸 道路(平均幅員 4.5 メートル)は、 三日月型の海 岸線 (総延長 1

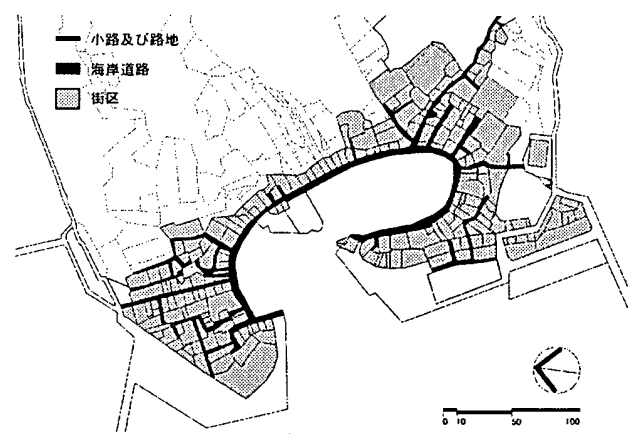

[図5] 街路網

キロ弱)に並行

して、南北両端を慗いでいる。この海岸道路沿いに2階〜3階建ての町並 みが形成され、ここでは毎年2回金比羅祭り*19が催された。また、この海岸 道路とそれに直行して街区 内部や丘人通じる小路(幅 員1.8〜 3m)が敷設され、基 本的な街区を構成している。 北端部と南端部の街区内 部には多数の路地があるが、 東側の街区は丘へ通じる地 形のため、階段の路地が多 い[図5]。さらに、街区内部 は小路に沿って敷地割りさ れて曲線である海岸道路と

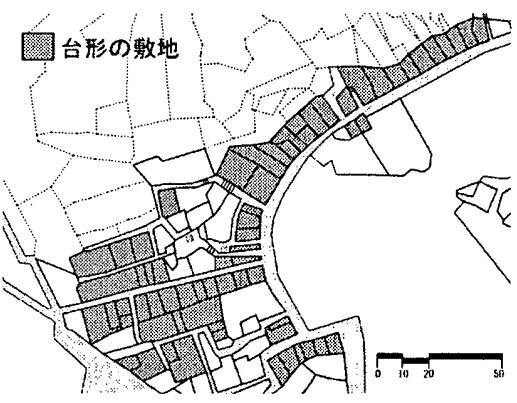

[图6] 街区構成
それに直行する小路により、街区内部の敷地は基本的に台形になっている [図6]。また、海岸道路に面する敷地の形は幅より奥の方が長い短冊型が 大部分で、その幅員の大半は4.5〜6メートルである。現在は2つあるいは3 つの敷地が統合されつつあるが、その規模はそのまま維持されている。
4-3 井戸と街区コミュニティー

井戸は島とい う地理的制約に よって開拓初期 から1930年代に かけて住宅地の 形成過程に重要 な要素として作 用していた。 1940 年に入り、 島の人口が急增 したため、韓国

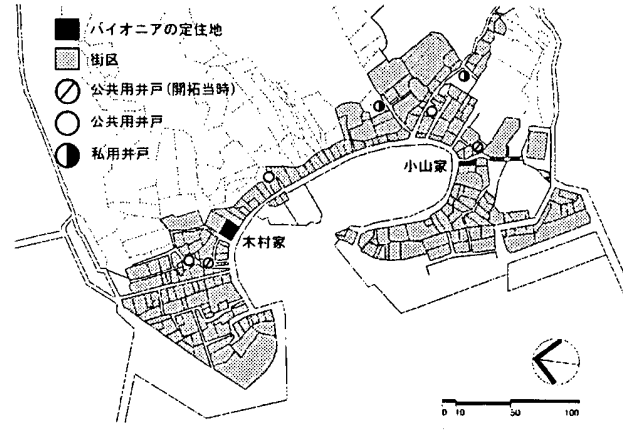

[図7] 井戸の位置
の本土や水場か

ら伝馬船*20で飲料水を運んで充足していた。1930年代までに掘られた井 戸の数は全部で7つで、その内公共用の井戸は5つ、私用が2つであった。 最初に掘られた井戸は2つで、その位置は木村と小山の定住地の近くにあ った。やがてこの2つの定住地が集落の核となり、1910年から20年にかけて、 多数の人々の移住により、3つの井戸が順に掘られ、水は手やポンプで汲 み上げられた。それらの井戸を中心に人々が住み着き、井戸は家事の作 業場、そして又、コミュニティー場として役割を果たした。私用の井戸は 1940年初に伝馬船により給水事情がよくなった際に開発され、それぞれ遊 廓と料亭の庭園用水に使われた[図7]。*21

\section{4-4 都市的機能の形成}

巨文港は開拓初期か ら1945年に至るまで近 代的な港町として発展し 続ける。韓国の他の著 名漁港に比較して、規 模(人口、面積など)が極 めて小さい漁村であった が、その機能分布から みると都市のような漁 業・遊興・商業の一大セ ンターであった。しだ って、3章の形成の背景 及び形成過程を踏まえ て、4章で施設分布、街 区構成と街路体系、更 に井戸と街区コミュニテ イーを総合的に考察した 結果、以下のように3段 階の都市的機能形成過 程が説明できる[図8]。

1)第1段階(1905年～1 910 年代)

(1)住居・商業施設群 (北側〜東側)

一木村の定住地を中 心として
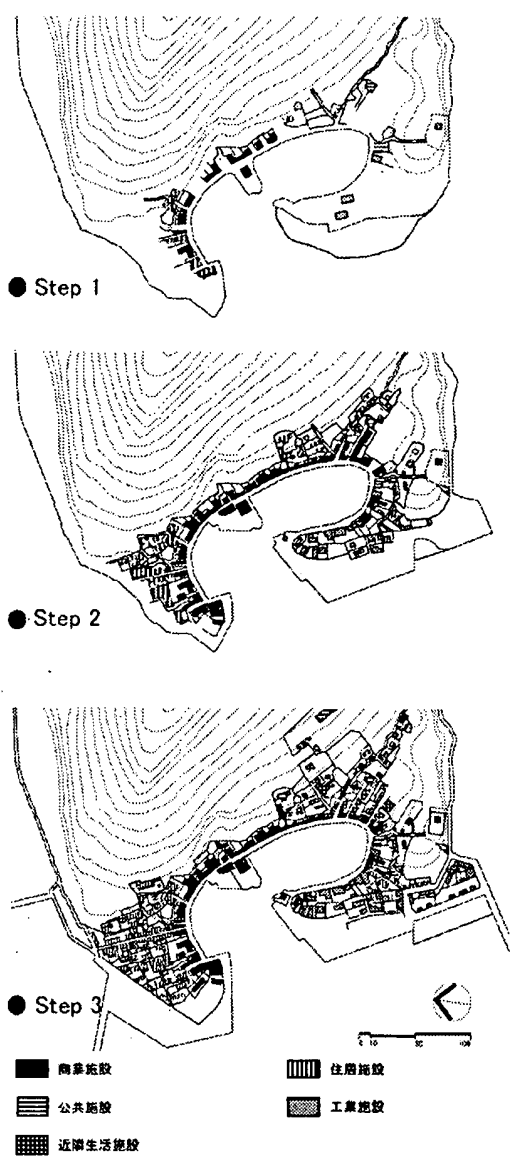

[図8] 都市的機能形成の過程

(2)公共·工業施設群 
(南側〜西側)一小山の定住地を中心として

2)第2段階(1920年代)

(1)住居施設群(北側)一住居施設の密集と路地の形成

(2)店舗施設群(東側)一海岸道路沿いに商店が建て込む

(3)公共施設群(南側)一郵便局、役所、警察署等の施設

(4)工業施設群(西側)一磯の部分が埋め立てられ、漁業関連の工業施設

(造船所、鉄工所、製水所、缶詰工場、発電所、倉庫など)が建設

3)第3段階(1930年 1940年代)

(1)住居施設群(北側)一住宅地と路地の拡大

(2)店舖施設群(東側)一住居機能を店舗併用住宅への転用

(3)遊興施設群(南東側)一風呂屋、料亭、遊遊、喫茶店、芝居小屋等の

遊興施設增加

(4)公共施設群(南側)一小学校、宗教施設の設置

(5)工業施設群(西側)一漁港施設の整備

\section{5.まとめ}

以上、その形成過程に基づき、日本人移住漁村としての巨文島の空間 構造の特徵は次のように要約できる。

1）集落空間の主な要素として、海岸線及び道路、井戸、パイオニアの 定住地の3つがあげられる。

2）集落の街路は、三日月型の海岸線に沿う海岸道路とそれに直行する 小路で形成された。また、街区は小路で敷地割りされ、街区の形態は曲線 である海岸道路とそれに直行する小路により、敷地の形態は台形である。

3）井戸は島という地理的制約によって開拓初期から住宅地の形成過程 に重要な要素として作用していた。井戸は7つあり、その中で特に 2 人のパ イオ二アの定住地周辺に掘られた $2 つ の$ 共同井戸は住宅地形成・発展過 程の核となった。その井戸周辺に人々が住み着き、井戸は作業場、そして コミュニティー場としての役割を果たした。

4）巨文港は、人口、面積など規模の小さい漁村ではあるが、漁業・遊 興・商業等の施設を備えた都市的機能を有する集落である。

変容過程に関する住居と建造物の実測調查やヒアリング調査に基づい た研究成果は別稿で報告する予定である。また、他の日本人移住漁村との 比較研究を進めたい。

注

*1 吉田敬市、朝鮮水産発達史、朝水会、1954

*2孫禎睦、日帝強占期都市化過程研究、一誌社(韓国)、1996

*3 巨文島についての記録は、9世紀(836年)の滋覚大師円仁の「入唐求法巡礼行 記小、15世紀の「世宗実録」、16世紀の「新增東国與地勝覽」などの様々な歷史書に残 られている。

*4 敨永甫、巨文島風雲史、三和文化社(韓国)、1986

*5 崔吉成、日本植民地之文化変容一韓国·巨文島、御茶の水書房、1994

*6 中村均、韓国巨文島につぼん村一海に浮かぶ共生の風景、中公新書、1994 *7 主に19世紀の東アジアの情勢に関する研究で、朴準用の「外交史的にみた韓末 政局と巨文岛事件(1967)」、崔文衡の「列強の東アジア政策(1979)」と「ロシアの太平 洋進出企図と英国の対応策(1981)」、李用熙の「巨文島占領外交綜收(1964)」、元裕 漠の「文島事件(1969)」、田保橋潔の「近代日鮮関保の研究(1940)」、Dallton,D.J.の 「The Rise of Russia TH.Asia, New Haven, Yale University Press(1949)」の等がある。 *8 日本人移住漁村の集落空間構成と異なる韓国独自の漁村の特徽をまとめて みると、(1)海岸道路沿いに連続的に町並みが形成されていないこと、(2)2階建 てがほほ見られないこと、(3)路地の形が直線ではないこと等が挙げられる。
*9 吉田敬市、前掲書、p.267 271

*10 孫禎睦、前掲書、 p. $462 \sim 473$

*11 万莱集の「巻第十五」の内容は、「天平八年丙子夏六月、新羅の国に遣ひ使は さるる時、使人等、各別れを悲しみ贈り答へ、また海路にて情を働み思ひを陳へてよ める歌」であり、当時の日本から新羅までの海路に関する内容は、3578〜3582節に当 る(鹿持雅澄、万葉集古義、国書刊行会、1912-1914)。これに関して中村は「当時、新 羅まで行く遗随使の出発地は:武庫の浦(現在の神戸)または難波の三津浦(現在の大 阪、三津寺町代多く、瀬戸内海を横切り、北九州に出て、荒津の港から一気に玄海 灘へ入るコースを取った。九州から新羅に行くのに朝鮮半島の南の海に浮かぶ孤島 の巨文島にわざわざ立ち奇る必要はない。しかし、航海に何らかの支障があれば、当 然、瑿急避難したことは考えられる。」と記述している(中村均、前揭書、p.3〜6)。 *12 次の4つである。

(1)北路(筑紫一対馬一巨文島一朝鮮半島の南西海岸を北上一山東半島)

(2)海道航路(筑紫一巨文島一朝鮮半島の南西海岸一揚州)

(3)南路(筑紫一平戸一五島列島一東シ十海一長江)

(4)南島路(筑柴一種子馬・神縄本島一東シナ海一長江)

*13 崔吉成、前掲書、p. $45 \sim 52$

*14 崔吉成、前揭書、p. 52 - 55

*15「集落の発展とその過程」の図面は、崔吉成と中村均の著書の中の図面を下敨 きにして、現在の地籍図 $(1 / 1,200)$ 、航測図 $(1 / 3,000)$ 、建築物管理台帳の内容など を合わせて、筆者が再作成したものである。

*16 韓国における行政区域の単位で、日本の「村」に当る。

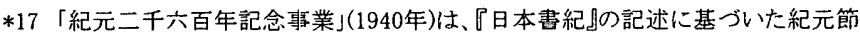
として神武天皇の即位から 26100 年目を数えた年を記念して行われた記念事業である。 こうした記念事業及び行事は朝鮮·台湾・樺太・関東州·南洋群島といった日本植民 地においても大々的に行わ扒、满州国皇帝の訪日もあわせて行なわれた。

*18「指定港指定制度」とは、朝鮮総督府令によって制定されたもので、漁業及び海 運業の奖励策としてつくられた制度である。その要件としては、(1)港が全国漁業の根 拠地になり得ること、(2)地方の漁船の数が一定の数に達すること、であった。 *19 海を生活の場とする巨文島においては、金比羅祭りが一年を通じて最も盛大に 催された。航海安全の神様である“金比羅さん”は島の主祭神であり、入り江南端の小 高い丘の上に位置していた。春(3月15日)と秋(10月10日)に行われる大祭では、青年 団が神舆を担いで朝に神社を:出発し、島中の全ての道(総延長 1 キロ弱)を何度も練り 歩いた後、昼過ぎに海に突入した。神興が突入すると同時に海へは紅白の餅が投げ 込まれる。夕方には、神社に汪る階段に露店が立ち並び、境内では各商店のくじ引き が行われていた。

*20 伝馬というのは、违送用の馬で、律令制では、駅馬とは別に、各郡に五匹ずつ 飼わせ、公用旅行の官人に使わせた。戦国時代以降は宿駅に備えて幕府、領主の公 用に供し、江戸時代には民間の輸送にも従った。(広辞苑、第4版)ここでは、水場で敛 料水を汲み、運送する船を意味する。

*21 中村均、前掲書、p. $120 \sim 137$

\section{参考文献}

[1] 吉田敬市、朝鮮水産発達史、朝水会、1954

[2] 孫襀睦、日帝強占期都市化過程研究、一誌社(韓国)、1996

[3] 效永甫、巨文島風雲史、三和文化社(韓国)、1986

[4] 崔吉成、日本植民地と文化変容一韓国・巨文島、御茶の水書房、1994

[5] 中村均、韓国巨文島にっぽん村一海に浮かぶ共生の風景、中公新書、1994

[6] 三山面誌発刊委員会、三山面誌、三山面(韓国)、2001

[7] 朝鮮総督府、朝鮮の聚落:(前·中·後編)、朝鮮総督府、1933

[8] 布野修司、インドネシアにおけ引る居住環境の变容とその整備手法に関する研究

一ハウジング・システムに関する方法論的考察、東京大、博論、1987

[9] 金泰永、開港場外人館研究、ソウル大(韓国)、博論、1991

[10] 韓三建·布野修司、日本植民統治期における韓国蔚山・邑城地区の土地所有 の変化に関する研究、日本建築学会計画系論文集、第520号、pp.219２26、1999.6.

[11] 飯塚キヨ、植民都市の空:間形成、大明党、1984

[12］権赫在、韓国地理、法了社(韓国)、1999

［13］鹿持雅澄、万葉集古義、国書刊行会、1912-1914 